DOI: https://doi.org/10.32839/2304-5809/2021-11-99-16

УДК 81.42

Білецька T.O. ${ }^{1}$, Гаврилюк O.O. ${ }^{2}$

Київський національний університет імені Тараса Шевченка

\title{
ЛІНГВОПРАГМАТИЧНІ ДОМІНАНТИ МОТИВАЦІЙНОЇ ПРОМОВИ СПОРТИВНОГО ТРЕНЕРА
}

\begin{abstract}
Анотація. Стаття присвячена вивченню особливостей мотиваційної промови спортивного тренера в сучасній англійській мові. У дослідженні визначено провідні домінанти мовленневого жанру мотиваційної промови загалом та мотиваційної промови спортивного тренера зокрема. На матеріалі мотиваційної промови відомого футбольного тренера Пепа Гвардіоли виділено ключові характеристики сучасних спортивних англомовних мотиваційних промов. Відзначено, що сучасний дискурс спортивних англомовних мотиваційних промов формують виступи тренерів, що не завжди є англійцями, а адресатом повідомлення часто постає інтернаціональний колектив футбольної команди, проте вимоги до володіння англійською мовою як мовою міжнародного спілкування нівелюють мовний бар'єр та роблять зміст промови доступним для всіх. Підкреслено, що зміст мотиваційної промови спортивного тренера на сучасному етапі сфокусований, у першу чергу, на використанні позитивних стратегій впливу на гравщів, покликаний спонукати їх не думати про результат, зосередитися на демонстрації найкращих якостей, об'єднати їх навколо загальнокомандної ідеї. Ключові слова: дискурс, мотивація, мотиваційний дискурс, спортивний дискурс, мотиваційна промова.
\end{abstract}

Biletska Tetiana, Havryliuk Olha Taras Shevchenko National University of Kyiv

\section{LINGUOPRAGMATIC DOMINANTS OF A SPORTS COACH'S MOTIVATIONAL SPEECH}

Summary. The article is devoted to such a topical issue of modern discursive analysis as the specifics of the motivational speech of a sports coach in modern English. From the point of view of psychology, motivation is defined as the motivation to act; psychophysiological process that controls human behavior, sets its direction, organization, activity and stability; human ability to meet their own needs. In this case, motivation consists of needs, motives and goals. If we consider motivation from the point of view of linguistics, it is possible to understand it as a set of examples for the expression of the psychological component in linguistics. The growing importance of motivational discourse for modern English-speaking society can be confirmed by the presence of separate oral and written genres that perform a motivational function. Oral genres of English motivational discourse include, in particular, "commencement speech» - introductory speeches at the graduation ceremony, «pep talk» - the speech of the coach before the match, "keynote speech» - the motivational speech of a famous person at a corporate event, as well as sermons. performing a motivational function. Written genres are represented by numerous «motivational books». The study identifies the leading dominants of the speech genre of motivational speech in general and motivational speech of a sports coach in particular. The key characteristics of modern sports English-language motivational speeches are highlighted on the basis of the motivational speech of the famous football coach Pep Guardiola. The article claims that the modern discourse of sports English motivational speeches is formed by the speeches of coaches. Though they are not always English, and the message is often addressed to the international football team, the requirements to English as the language of international communication remove the language barrier and make the speech accessible to everyone. It is emphasized that the content of the motivational speech of a sports coach at the present stage is focused primarily on positive strategies to influence players, designed to encourage them not to think about the result, demonstrate the best qualities, unite them around the team idea.

Keywords: discourse, motivation, motivational discourse, sports discourse, motivational speech.

$\Pi$ остановка проблеми. Протягом останніх десятиліть аналіз дискурсу залишаеться актуальною сферою лінгвістичних студій. Як зауважуе Т. А. ван Дейк, дискурс водночас є лінгвістичним об'єктом, оскільки складається 3 осмислених слів та речень; також він е дією, формою соціальної взаемодії, соціальною практикою, ментальною репрезентацією, інтеракційною або комунікативною подією, продуктом культури або ж навіть товаром [15, с. 82].

Дослідники виділяють численні типи дискурсу: політичний, педагогічний, релігійний, медійний, комп'ютерний і т. ін. Особливе місце в структурі системи дискурсів займае мотиваційний дискурс.
Аналіз останніх досліджень і публікацій. Протягом останніх кількох років побачили світ роботи таких авторів, як Т. А. ван Дейк [15], Дж. Лемке [12] та ін., присвячені функціонуванню дискурсу в соціумі. В 2011 році вийшов спеціальний номер часопису «Pragmatics and Society», присвячений дискурсу сощіальних досліджень [9].

Такий жанр мотиваційного дискурсу, як демотиватори, були досліджені в роботах Л.В. Бабіної [1], I.В. Бугайової [3], Н.Г. Брагіної [2], однак до сих пір комплексні дослідження такого жанру, як мотиваційна промова спортивного тренера, не проводилися.

Виділення невирішених раніше частин загальної проблеми. Мотивація є невід'ємною 
складовою спортивного дискурсу. Відтак, цілком правомірно стверджувати існування мотиваційного дискурсу, який ми пропонуемо визначати як вербальну взаємодію адресанта і адресата 3 метою надання позитивного впливу на емоційну, вольову та діяльнісну сорери останнього. Подібно до інших типів дискурсу, мотиваційному дискурсу притаманний цілий набір характеристик, що потребують всебічного вивчення.

Незважаючи на це, жанри мотиваційного дискурсу, зокрема, мотиващійні промови спортивних тренерів, та мотиваційний дискурс в цілому вивчені недостатньо. Мотивацію та похідні від неї дискурси переважно вивчають представники психологічних наук. Так, зокрема, в роботі В.О. Климчука 3 точки зору психології розглянуті чотири центральні теми мотиваційного дискурсу, серед яких виділено дискурс автентичності, дискурс оцінювання, дискурс експансії та дискурс конструювання. Проте відсутні саме лінгвістичні, а надто - лінгвопрагматичні дослідження, присвячені наведеній проблемі [4]. Тому, на нашу думку, необхідним постає проведення всебічного аналізу мотиваційного дискурсу з точки зору лінгвопрагматики.

Формулювання цілей статті. Мета дослідження: з'ясувати лінгвопрагматичні домінанти мотиваційних промов спортивних тренерів як складової сучасного англомовного спортивного дискурсу.

Виклад основного матеріалу дослідження. 3 точки зору психології, мотивація визначаеться як спонукання до дії; психофрізіологічний процес, що керує поведінкою людини, задає їі спрямованість, організацію, активність та стійкість; здатність людини самостійно задовольняти власні потреби [1]. У такому випадку мотивація складається із потреб, мотивів та цілей. Якщо ж розглядати мотивацію з точки зору мовознавства, то можливим постає їі розуміння як сукупності прикладів для вираження психологічної складової в лінгвістиці.

Зростання важливості мотиваційного дискурсу для сучасного англомовного соціуму можна підтвердити наявністю окремих усних та письмових жанрів, що виконують мотиваційну фрункцію. До усних жанрів англомовного мотиваційного дискурсу можна віднести, зокрема, «соmmencement speech» - настановчі промови на церемонії закінчення університету, «рер talk» - промова тренера перед матчем, «keynote speech» - мотиваційна промова відомої людини на корпоративному заході, а також проповіді, що виконують мотиваційну фрункцію. Письмові жанри представлені численними «motivational books».

Характерною особливістю мотиваційного дискурсу $є$ наявність креолізованого (полікодового) жанру - мотиваторів та демотиваторів, а також поява такої профресії, як «motivational speaker».

Навіювання тих чи інших ідей відбувається шляхом відбору та подальшого компонування фрактів, що доводять, а не спростовують авторську позицію. Вирішальним чинником у переконанні реципіента стає вміння користуватися арсеналом риторичних засобів та прийомів, що дозволяють перевести модальність мовлення 3 поля суб'єктивного сприйняття до поля об'єктивного і верифрікованого знання. Особливо слід наголоси- ти на тому, що відправник повідомлення, свідомо варіюючи його змістом на сигніфікативному рівні, задає напрямок думки і в подальшому управляє увагою отримувача. Через це в жанрах, де риториці відводиться важлива роль, спостерігається тенденція до приховування одних аспектів денотативної ситуації на користь інших. Автор кожного тексту, виділяючи щось конкретне, тим самим прибирає 3 поля зору реципіента інші аспекти того, що описується чи обговорюється [1, с. 79].

Персуазивність структурно організованого мотиваційного тексту стверджуеться в роботах багатьох дослідників прагматики мовленнєвих жанрів. Р. Кокс, покликаючись на міркування К. Берка про мову як символічну дію, розширюе межі реалізації поняття персуазивності аж до нейтрального способу вираження мовлення, який також є виявом переконання, оскільки спирається на символічне відтворення дійсності [6, с. 18].

Відносно наукової сфери висування та поширення певного міфу ініціюеться автором мотиваційного тексту - свідомо чи несвідомо - в результаті обгрунтування або бездоказового твердження. Без сумніву, «природний шлях міфрологізації знання проходить через підкорення знання особистісним світоглядним переконанням» [5, с. 17].

Наразі існуе відносно велика кількість наукових досліджень, присвячених визначенню особистісних якостей та характеристик спортивного тренера. Часто стверджується, що успішний тренер повинен бути моральним, авторитетним, освіченим, бути командним гравцем, комунікативним і компетентним. На думку П. Робінсона, в роботі спортивного тренера важливою складовою $є$ вміння планувати й аналізувати, а також підтримувати безпечне середовище, що буде сприятливим для навчання, зростання й розвитку кожного його підопічного [13].

Згідно з ідеологічними настановами тренерської практики як такої спортивний тренер своїм основним завданням вбачає розкриття внутрішнього потенціалу спортсменів, що тренуються та працюють під його керівництвом. Після невдалих результатів або внаслідок впливу зовнішніх та внутрішніх чинників вони можуть бути деморалізованими, що неминуче позначатиметься на їхній результативності. При цьому слід зауважити, що така ситуащія для спортсмена як для людини, чия професійна діяльність пов'язана із досягненням певних результатів, $€$ неприпустимою, тому в цьому випадку інтереси тренера та його прагнення вивести підопічного із стану апатії перетинаються з інтересами самого спортсмена, тому мовленневі та інші маніпуляції в цьому разі орієнтовані на користь об'єктів маніпуляції [11].

Спортивний тренер має ефрективно спілкуватися зі своїми підопічними, забезпечуючи конструктивний зворотній зв'язок, а також бути мотивованим до безперервного навчання й розвитку. Тренер має турбуватися про кожного окремого спортсмена, що тренуеться чи займається під його керівництвом, й така готовність до самопожертви сприяе виникненню позитивного мікроклімату в команді, яка очолюеться тим чи іншим фрахівцем. Він повинен постійно навчатися й розвиватися, відтак, відкритість до навчання має першочергове значення [13]. 
Завдяки партнерським відносинам із численними учасниками спортивного процесу, заснованим на взаємній повазі та розподілі важливості виконуваної роботи, діалозі та побудові загального сенсового простору, тренер створюе загальне середовище спортивної команди, де кожен його учасник отримує змогу навчатися, розвиватися та вдосконалюватися. На додачу до освіти, виховання та якостей, отриманих на основі досвіду, кожен тренер має власну імпліцитну профресійну dpiлософрію, яку тим чи іншим чином доносить до своїх підлеглих під час тренувального процесу [6].

Ця імпліцитна профресійна фрілософрія вказує на глибокі та приховані мотиваційні чинники, важливі для успішної роботи окремого тренера. Вона може розглядатися як набір моральних переконань та позицій, що фрормують поведінку тренера в тій чи іншій професійній та побутовій ситуації, при цьому в різних тренерів наявні різні домінанти профресійної фрілософрії відносно їх власної ролі в команді, тобто причини, через які вони займаються тренерською справою.

Невід'ємною складовою роботи кожного тренера, його спортивного дискурсу, є мотиваційні промови. Вони стають простором реалізації профресійного кредо кожного тренера, адже саме там фахівещь отримує змогу сформулювати свої вимоги до підопічних таким чином, аби спонукати їх до покращення поточних результатів чи їх збереження, у разі, якщо ці результати вже $є$ позитивними або максимально можливими. Зміст мотиваційної промови має особливе значення, оскільки з його допомогою тренер може виразити власні емоції у зв'язку з матчем чи змаганням, висловити свої побажання гравцям, внести необхідні корективи, якщо команда недостатньо добре налаштувалася на гру, через що страждає результат. Відповідно до поставленої мети, можна виділити такі типи мотиваційних промов:

1) промови контролювального спрямування;

2) стратегічно орієнтовані промови;

3) емоційні промови, що мають найбільший потенціал для мотивування спортсменів, оскільки в них наявний сильний емоційний меседж, спрямований на необхідність досягнення успіху [16].

В якості прикладу розглянемо мотиваційну промову головного тренера англійського фрутбольного клубу «Манчестер Сіті» Пепа Гвардіоли, виголошену ним у перерві фрінального матчу Кубку Англійської Ліги сезону 2019/2020, де «Сіті» грав проти іншого лондонського клубу «Арсенал». Після першого тайму команда з Манчестера поступалася, тому в перерві каталонський фрахівець мав мотивувати своїх підопічних для того, аби вони змінили хід поєдинку, що складався для них невдало.

Перед тим, як перейти до безпосереднього аналізу змісту мотиваційної промови Пепа Гвардіоли, звернімо увагу на постать самого тренера. Гвардіола є іспанцем (каталонцем) за походженням, відтак, англійська мова не є для нього рідною, проте, працюючи на посаді головного тренера одного з провідних фрутбольних клубів Англії, він досконало опанував цією мовою, відтак, проблем із проведенням мотиваційних настанов для нього не було. При цьому слід зауважити, що Пеп Гвардіола є справжнім поліглотом і успішно вивчив мови тих країн, де працював протягом своєї фрутбольної кар'єри - так, окрім рідної каталонської, він володіе також німецькою та англійською мовами. Окрім того, «Манчестер Сіті», будучи своєрідною «збірною світу», подібно до інших успішних фотбольних клубів, має у своєму складі гравців, що є представниками інших країн, проте всі вони знають англійську мову на рівні, достатньому для профресійної комунікації, тому комунікативний бар'єр між ними та Гвардіолою був маловірогідним.

Розглянемо текст мотиваційної промови Пепа Гвардіоли, оприлюдненого на офіційному каналі «Манчестер Сіті» на відеохостингу Youtube [10]. Визначимо ключові параметри наведеної мотиваційної промови Хосепа Гвардіоли. Тривалість виступу головного тренера склала 2 хвилини та 56 секунд, у промові було використано 325 слів. Аналізована мотиваційна промова була виголошена в перерві фрінального матчу Кубку Англійської Ліги сезону 2019/2020, на стадіоні «Вемблі» в Лондоні.

Це був не перший досвід виступу «Манчестер Сіті» в фінальних матчах на такому рівні, проте для тренера було важливо донести до своїх підопічних думку про необхідність змінити поточний результат на свою користь, для чого потрібно було максимально мотивувати гравців манчестерської команди, аби вони продемонстрували свої найкращі якості в другому таймі. Під час промови головний тренер був розташований обличчям до гравців, а за його спиною була розміщена ширма.

Зміст виголошеної тренером мотиваційної промови проаналізовано на кількох рівнях. На першому рівні він був розділений за трьома значущими блоками таким чином:

1) Обізнаність стосовно ситуації

2) Завдання (мета);

3) Заклик до єдності й упевненості.

3 методологічної точки зору блок «Обізнаність стосовно ситуащіі» (надалі - просто "Ситуація») включає такий фррагмент тексту мотиваційної промови Гвардіоли: "All of us have to take a maturity test. After all, our maturity is challenged today in the best and most beautiful way. It's our graduation day today, a football one. We are playing the League Cup final match against the best opponent in the world. With Arsenal. And I want to tell you we need to enjoy today. There should be no pressure, except our desire to win. It is the basic urge we were born for, that's why we play football. To enjoy and win, is that right?» [10].

Значущий блок «Завдання (мета)» був представлений такими фррагментами тексту: «I want to tell you that no one should excell today. You have already done it. In what sense? Individually, fighting for your own reputation. All of you who are here today, everybody already knows about you. Top professional careers are waiting for you. Today we need to play for the team. Today we need to be united, as we have been so far. And even more! Whoever our opponent is, we, guys, deserve it. This trophy (указує на світлину із зображеннял Кубку Англійської Лiгu). We, guys, are born to win this trophy. Look at it closely, it should be ours. Anyway, we should only give our best. As we have been doing so far. Today we need to seal a victory (плескае кулакол по своїй долоні). Today is our graduation day! (викидає 
вгору кулак у войовничолу жесті). Today we are taking our final exam, we are graduating today! We are going home with the gold!» [10].

Значущий блок «Заклик до едності й упевненості» (далі - просто «Заклик») представлений таким фррагментом тексту мотиваційної промови головного тренера "Манчестер Сіті»: «I want you all guys to stand up now. I want you to hug each other, as we did last time, I want all of us to hug each other. And, guys, I don't want you to pray now, I want you to look each other in the eyes. Anyone who needs to keep their eyes closed, let them do it. And think about why we are worth it. What everyone of you has done in their life to deserve this (указуе на Кубок Англійськоӥ Ліги, зображений на світлині, шо знаходиться в руках у тренера). Who everyone of us is and who we want to win this trophy for. Please hug each other, let us feel each other. Let's remain silent for a minute. To feel the unity. To look each other in the eyes and tell to each other that we are going to do it for each other. To do it for us, for all of us» [10].

Весь текст, а також кожна окрема одиниця були проаналізовані індивідуально. У тексті мотиваційної промови Пепа Гвардіоли домінують дієслова: win, enjoy, play, і це природна практика, адже таким чином тренер акумулюе думки гравців навколо тих дій, які вони мають виконати після перерви, аби досягнути успіху. Іменник pressure актуалізований як номінація явища, яке є для Гвардіоли небажаним, відтак тренер пропонуе своїм фрутболістам позбавитися відчуття тиску та грати у власне задоволення.

Не менш важливу роль у промові каталонського тренера відіграє прислівник today, за допомогою якого наставник актуалізуе важливість конкретного фрінального поєдинку для його команди, а також висловлює впевненість, що саме в цей день «Манчестер Сіті» здобуде очікувану перемогу. В структурі промови тренера зазначений прислівник набуває ознак анафоричності. Автор промови цілеспрямовано вживає прислівник today повторюючи його на початку одразу кількох речень 3 метою наголосити на значущості та важливості того дня, а саме події в той день: "Today we need to seal a victory. Today is our graduation day! Today we are taking our final exam, we are graduating today!" [10].

Окрім того, в аналізованому фрагменті промови спостерігаємо реалізацію такої стилістичної фрігури, як висхідна градація. Об'єднані спільним ініціальним елементом, наведені речення втілюють поступовий перехід думки Гвардіоли від дещо банальної фррази про необхідність перемоги в сьогоднішній грі в першому реченні до порівняння фінального матчу із іспитом на атестат зрілості в другому та третьому реченнях Дейктик today оточуе мотивацію тренера 3 обох боків і створює певну завершену рамку з лексичними одиницями (victory, graduation day, take your final exam), спрямованими на перемогу. Це створює едект неминучості ситуації і здається, що іншого варіанту завершення матчу для його підопічних просто не існує: тільки сьогодні і тільки перемога.

Загальний мотиваційний ефект у цьму фррагменті досягається як вербальними, так і невербальними засобами. Окрім безпосередньо тексту промови головного тренера, його жестикулящія теж допомагає реалізувати стратегію мотивації.

Гвардіола, апелюючи до своїх підопічних, використовуе достатньо агресивні жести - адже маніпулювання кулакам під час виступу - очевидний заклик до того, аби його команда «завелася», спонукання до викиду накопиченої агресії на фрутбольному полі. Окрім того, будь-яка жестикуляція покликана привернути увагу до оратора, й каталонський тренер уміло використовує iï можливості, концентруючи увагу фрутболістів «Манчестер Сіті» на власній персоні.

Градація використовується Гвардіолою й у фрінальному фррагменті мотиваційної промови: «Let's remain silent for a minute. To feel the unity. To look each other in the eyes and tell to each other that we are going to do it for each other. To do it for us, for all of us» [10]. У ньому, на противагу загалом емоційній основній частині промови, каталонський тренер пропонуе своїм гравцям зосередитися та хвилину провести в цілковитій тиші, аби краще сконцентруватися й відчути, для чого вони грають і мають вигравати фінальний матч. Використання інфінітивів to feel, to look, to do на початку кожного наступного речення акцентуе мету.

Помітно, що основний зміст мотиваційної промови Гвардіола міг висловити в межах одного складного речення. Натомість, він умисно розділяє великий елемент своєї промови на кілька менших речень, немовби розриваючи висловлену в ньому думку. Тому у фррагменті: «Let's remain silent for a minute. To feel the unity" [10] цілком припустимо говорити про явище парцеляції, за допомогою якого тренер, очевидно, намагався виділити важливий мотиваційний компонент промови, відокремивши його від основної думки.

Як і в попередньому проаналізованому фррагменті, градація тут є висхідною, тобто Гвардіола поступово, кожним реченням підводить своїх підопічних до усвідомлення найважливіших настанов мотиващійної промови. Так, спочатку він пропонуе гравцям відчути єдність як важливу умову успішного командного мікроклімату. Після цього тренер радить фотболістам зазирнути один одному в вічі та поділитися думками стосовно того, як кожен із них може допомогти своєму партнерові по команді та всій команді в цілому, мотивуючи ïx таким чином працювати в команді під час гри. I, нарешті, Пеп Гвардіола наголошуе, що все, що роблять гравці в цей день на полі, вони мають робити не лише для себе, а для всіх, кого об'єднує ім'я «Манчестер Сіті» - фрутболістів, тренерів, уболівальників. Усі ці категорії небайдужих до команди осіб каталонський тренер маркуе дейктичним елементом, особовим займенником us, який кілька разів повторюе, виділяе голосом та прагне сконцентрувати увагу своїх підопічних на важливості саме такого позначення «...To do it for us, for all of us» [10]. Це викликає почуття відповідальності перед іншими і також має мотивувати гравців на перемогу.

Аналізуючи текст мотиваційної промови Гвардіоли, можна відзначити, що каталонський тренер акцентує увагу гравців на тому, що найбільшу цінність становить саме гра, а не перемога чи статус змагання. Він не тисне на гравців, не перебільшуе та не применшуе чесноти суперника. Гвардіола зумисно знижуе «градус» значу- 
щості фрінальної гри, який традищійно є високим. Тренер пропонуе своїм гравцям забути про те, наскільки важливим є цей матч, зосередившись на красі гри.

Головний меседж Гвардіоли, адресований його підопічним, може бути сформульований таким чином: "I want, we need to, we want to enjoy, win today" [10]. Такі позитивно орієнтовані дискурсивні звертання є домінантними в усьому тексті.

Результати дослідження доводять, що Пеп Гвардіола у своїй мотиваційній промові повністю орієнтований на повернення своїм гравцям позитивного сприйняття гри, упевненості в собі, що, безперечно, трохи похитнулося після невдало проведеного першого тайму. Для цього він часто вдається до вживання займенників (we, us, all), іменників (guys), дієслів (want), що актуалізують стратегї̈ об'єднання. Таким чином, спостерігаємо, що Гвардіола зумисно мінімізуе відстань між собою та командою (we, us, all, guys), прагнучи об'єднати футболістів навколо своїх ідей.

Аналіз трьох провідних значущих блоків, на які було розбито мотиваційну промову Пепа Гвардіоли в перерві фрінального матчу Кубку Англійської Ліги сезону 2019/2020, дозволив виділити такі провідні стратегії спонукання гравців «Манчестер Сіті» до покращення власних результативних показників:

1. Пропозиція до гравців насолоджуватися грою, забувши про будь-який тиск результату, що тяжіє над командою («There should be no pressure, except our desire to win. It is the basic urge we were born for, that's why we play football. To enjoy and win, is that right?» [10]);

2. Апеляція до опонента, без перебільшення та применшення його сили, титулованості («Arsenal...Whoever our opponent is» [10]).

3. Апеляція до інстинктів гравців («Basic urge, to play, win. Born to win this trophy...» [10]).

4. Підвищення рівня впевненості гравців у власних силах ("You have already excelled..." [10]).

5. Підвищення рівня впевненості гравців у власних силах із залученням апеляцій до щасливого майбутнього («Top professional careers are waiting for you...» [10]).

6. Окреслення головної мети («Today we need to play for the team..." [10]).

7. Акцентування на тій нагороді, яку команда отримає, якщо повірить у власні сили («Trophy: this should be ours..." [10]).

8. Використання релятивізації для зниження тиску на гравців перед другим, вирішальним таймом ("Anyway, we should only give our best...» [10]).

9. Порівняння гри із випускним вечором, іспитом на атестат зрілості («Today is our graduation day! We are taking the final exam, we are graduating today! We are going home with the gold!» [10]).

10. Актуалізація командного духу, прагнення змусити кожного гравця відчути себе частиною команди, единого цілого ("I want you all to hug each other. As we did last time, please hug each other, everyone... I want you all to look each other in the eyes... To feel the unity" [10]).

11. Вираження поваги до індивідуальності кожного гравця ("Anyone who needs to keep their eyes closed, let them do so» [10]).

12. Урочиста обіцянка, адресована команді («To do it for each other ...» [10]).
Повідомлення Гвардіоли, що складають структуру мотиваційної промови, в переважній своїй більшості $є$ позитивно забарвленими. Тренер просить своїх гравців не просто грати на результат, а робити це красиво. Таким чином, він мотивуе їх отримувати задоволення від гри та намагається знизити тиск перед вирішальним періодом фрутбольного матчу, на який його підопічні вийдуть, будучи змушеними відіграватися.

Пеп Гвардіола одночасно мотивуе як кожного окремого гравця, так і всю команду. Він декларуе повагу до індивідуальності своїх підопічних, але нагадує їм, що вони є гравцями прекрасної команди, унікальної у своїй єдності. Актуалізуючи мету, поставлену перед «Манчестер Сіті» у фіналі, Гвардіола демонструє впевненість у тому, що вона буде досягнута, спонукаючи фрутболістів повірити в це так само, як вірить головний тренер: "And, guys, I don't want you to pray now, I want you to look each other in the eyes. Anyone who needs to keep their eyes closed, let them do it. And think about why we are worth it. What everyone of you has done in their life to deserve this» [10].

Висновки 3 даного дослідження i перспективи. Отже, аналізуючи особливості мотиваційної промови спортивного тренера як популярного, проте досить недослідженого жанру мотиваційного дискурсу сучасної англійської мови, а також виступу відомого фрутбольного тренера Пепа Гвардіоли в перерві фрінального матчу Кубку Англійської Ліги сезону 2019/2020, необхідно виділити такі провідні тези.

По-перше, в ході проведеного дослідження були розглянуті жанрові домінанти мотиваційної промови загалом та закономірності їх вираження у виступі успішного спортивного тренера. Важливим було виокремлення тих слів, фрраз, кліше, які постають ядерними в меседжах, що їх Пеп Гвардіола вважає за потрібне донести своїм підопічним, мотивуючи їх до спортивних звершень.

Слід при цьому зауважити, що адресатом повідомлення постає інтернаціональний колектив футбольної команди, де всі гравці на тому чи іншому рівні розуміють англійську мову, проте не для всіх вона є рідною. Відтак, від головного тренера, для якого англійська так само не $є$ рідною, проте він досконало нею володіє, вимагається добір таких мовних і мовленневих засобів, що максимізували б ефективність впливу його мотиваційної промови на фрутболістів та змусили їх мобілізувати власні фізичні й моральні резерви.

Аналізуючи дискурс мотиваційної промови Пепа Гвардіоли в перерві фрінального матчу Кубку Англійської Ліги сезону 2019/2020, необхідно виокремити такі провідні характеристики, що були для неї притаманними:

- промова була зрозумілою, тренер чітко визначив цілі, вирішення яких було необхідним для того, аби успішно мотивувати гравців;

- Гвардіола уникав таких прийомів, як приниження та знецінення команди суперника, до яких доволі часто вдаються спортивні тренери. В його виступі у роздягальні під час перерви dpiнального матчу Кубку Англійської Ліги не спостерігається використання тактик погроз, тиску чи висловлення негативних емоцій;

- тренер дав зрозуміти, що повністю розділяе із гравцями як відповідальність за результат фіналь- 
ного матчу, так і внесок до того успішного сезону, що й дозволив «Манчестер Сіті» дійти до фріналу престижного клубного турніру. Він підкреслив необхідність відповідності дій команди принципам красивої гри та єдності колективу, що, на думку Гвардіоли, є основою успіху під час спортивних змагань. Слід зауважити, що у своїй мотиващійній промові головний тренер абсолютно не зачіпав технічний бік гри та не апелював до окремих гравців.
По-друге, мотиваційна промова Пепа Гвардіоли, адресована гравцям «Манчестер Сіті» в перерві фрінального матчу Кубку Англійської Ліги сезону 2019/2020 років, була дуже важливою з точки зору педагогічної складової тренерської профресії. За допомогою мовленневих стратегій Гвардіола продемонстрував свою профресійну фpiлософрію, завдяки якій йому вдалося здобути високий авторитет у футбольному світі.

\section{Список літератури:}

1. Бабина Л.В. Об особенностях демотиватора как полимодального текста. Филологические науки. Вопросы теории и практики. Тамбов : Грамота, 2013. № 2. С. 28-33.

2. Брагина Н. "Демотиваторы со смыслом" и наивные толкования: о соотношении вербального и визуального. Антропологический фборул. Санкт-Петербург : ЛЕМА, 2014. № 21. С. 49-65.

3. Бугаева И.В. Демотиваторы как новый жанр в Интернет-коммуникации: жанровые признаки, функции, структура, стилистика. URL: http://rastko.rs/filologija/stil/2011/10Bugaeva.pdf (дата звернення: 12.10.2021).

4. Климчук В.О. Мотиваційний дискурс особистості: на шляху до соціальної психології мотивації : монографія. Житомир : Вид-во ЖДУ ім. І. Франка, 2015. 290 с.

5. Коломыц Д.М., Коломыц О.Г. Мифотворчество в исторической науке: мифология в источниках и субъективизм исследований. Вестн. Казан. гос. ун-та культуры и искусств. 2016. № 4. С. $13-17$.

6. Cassidy T., Jones R., Potrac P. Understanding sports coaching. The social, cultural and edagogical foundation of coaching practices. London and New York : Routledge, 2004. URL: https://coachiwanles.wordpress.com/2012/10/ coaching.pdf (дата звернення: 12.10.2021).

7. Cox R. Environmental Publication and the Public Sphere. Thousand Oaks : SAGE Publ., 2013. 429 p.

8. Crisfield P., Cabral P., Carpenter F. The successful coach, guidelines for coaching practice. Leeds, UK : The National Coaching Foundation, 2003.

9. Gill Ann M., Whedbee K. Rhetoric. Discourse Studies: A Multidisciplinary Introduction. London; Thousand Oaks; New Delhi : SAGE Publ., 1998. V. 1: Discourse as Structure and Process. P. 157-184.

10. Guardiola's FIERY Speech to His Players During the League Cup Final Against Arsenal. URL: https://www.youtube.com/watch?v=ZVprYvnfxKo (дата звернення: 12.10.2021).

11. Leidl D., Frontiera J. A Qualitative Analysis of Motivational Efforts Employed by Elite Lacrosse Coaches. Journal of Coaching Education. 2009. No. 21. P. 73-98.

12. Lemke J. Discursive technologies and the social organization of meaning. Folia Linguistica. 2002. № 35 (1-2). P. $79-96$.

13. Robinson P. Foundations of Sports Coaching. London and New York : Routledge, 2010. URL: https://coachiwan. files.wordpress.com/2012/10/foundations_of_sports_coaching.pdf. (дата звернення: 12.10.2021).

14. The Discourse of Social Achievement. Special issue of Pragmatics and Society. 2011. Volume 2 . Issue 2.

15. Van Dijk T.A. Critical Discourse Studies; A sociocognitive Approach / Ruth Wodak \& Michael Meyer (Eds.), Methods of critical discourse analysis. London : Sage, 2009. P. 62-85.

16. Vargas-Tonsing T. M., Bartholomew J. B. An exploratory study of the effects of pregame speeches on team efficacy beliefs. Journal of Applied Social Psychology. 2006. No. 36:4. P. 918-933.

\section{References:}

1. Babina, L. (2013) About peculiarities of demotivator as a polymodal text. Philological sciences. Theoretical and practical questions, 2, 28-33.

2. Brahina, N. (2014) "Demotivators with sense" and naive sentences: about symmetry of verbal and visual. Forum of anthropology, 21, 49-65.

3. Buhayeva, I. (2011) Demotivators as a modern genre of Internet communication: genre characteristics, functions, structure, stylistics. Available at: http://rastko.rs/filologija/stil/2011/10Bugaeva.pdf

4. Klymchuk, V. (2015) Motivational discourse of individual: on the path to social psychology of motivation: monograph. Zhytomyr: Zhytomyr State University named after I. Franko Publishing.

5. Kolomyts, D., \& Kolomyts, O. (2016) Creating of myth in historical sciences: mythology in sources and subjectivity of studies. Messenger of Kazan State University of culture and arts, 4, 13-17.

6. Cassidy, T., Jones, R., \& Potrac, P. (2004) Understanding sports coaching. The social, cultural and edagogical foundation of coaching practices. London and New York: Routledge. Available at: https://coachiwanles.wordpress.com/ 2012/10/coaching.pdf

7. Cox, R. (2013) Environmental Publication and the Public Sphere. Thousand Oaks: SAGE Publ.

8. Crisfield, P., Cabral, P., \& Carpenter, F. (2003) The successful coach, guidelines for coaching practice. Leeds, UK: The National Coaching Foundation.

9. Gill Ann, M., \& Whedbee, K. (1998) Rhetoric. Discourse Studies: A Multidisciplinary Introduction. London; Thousand Oaks; New Delhi: SAGE Publ., V. 1: Discourse as Structure and Process, pp. 157-184.

10. Guardiola's FIERY Speech to His Players During the League Cup Final Against Arsenal (2020). Available at: https://www.youtube.com/watch?v=ZVprYvnfxKo

11. Leidl, D., \& Frontiera, J.A. (2009) Qualitative Analysis of Motivational Efforts Employed by Elite Lacrosse Coaches. Journal of Coaching Education, 21, 73-98.

12. Lemke, J. (2002) Discursive technologies and the social organization of meaning. Folia Linguistica, 35 (1-2), 79-96.

13. Robinson, P. (2010) Foundations of Sports Coaching. London and New York: Routledge. Available at: https://coachiwan.files.wordpress.com/2012/10/foundations_of_sports_coaching.pdf

14. The Discourse of Social Achievement (2011) Special issue of Pragmatics and Society, vol. 2, iss. 2.

15. Van Dijk, T.A. (2009) Critical Discourse Studies; A sociocognitive Approach. Methods of critical discourse analysis. London: Sage.

16. Vargas-Tonsing, T.M., \& Bartholomew, J.B. (2006) An exploratory study of the effects of pregame speeches on team efficacy beliefs. Journal of Applied Social Psychology, 36:4, 918-933. 